ENVIRONMENTAL RESTORATION PROGRAM

\section{The Use of Institutional Controls at Department of Energy Oak Ridge Field Office Environmental Restoration Sites}

MAR 121992

ES/ER/TM-28

es/

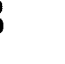


This report has been reproduced directly from the best avallable copy.

Avallable to DOE and DOE contractors from the Office of Scientific and Technical Information, P.O. Box 62, Oak Ridge, TN 37831; prices avallable from 615-576-8401, FTS 626-8401.

Available to the public from the National Technical Information Service, U.S. Department of Commerce, 5285 Port Royal Rd., Springfield, VA 22161. 


\title{
The Use of Institutional Controls at Department of Energy Oak Ridge Field Office Environmental Restoration Sites
}

\author{
R. K. White \\ D. W. Swindle \\ A. Redfearn \\ A. D. King \\ Environmental Restoration Division \\ P.O. Box 2003 \\ Oak Ridge, Tennessee 37831-7298
}

Date Issued_January 1992

Prepared by

Risk Analysis Section

Health and Safety Research Division

Oak Ridge National Laboratory

Prepared for

U.S. Department of Energy

Office of Environmental Restoration and Waste Management under budget and reporting code EW 20

MARTIN MARIETTA ENERGY SYSTEMS, INC.

managing the

Oak Ridge National Laboratory

Oak Ridge Y-12 Plant

Oak Ridge K-25 Site

Paducah Gaseous Diffusion Plant

under contract DE-AC05-84OR21400

and the

Portsmouth Gaseous Diffusion Plant

under contract DE-AC05-76OR00001

for the

U.S. DEPARTMEN'T OF ENERGY 
ABSTRACT $\ldots \ldots \ldots \ldots \ldots \ldots \ldots \ldots \ldots \ldots \ldots \ldots \ldots \ldots \ldots \ldots \ldots \ldots \ldots \ldots$

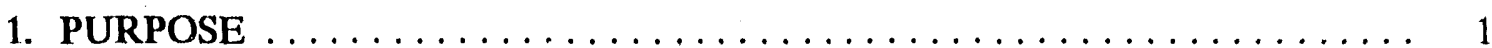

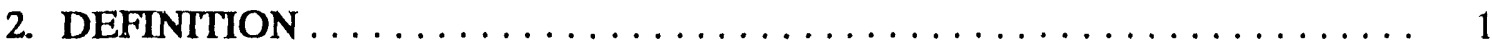

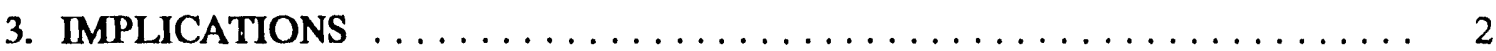

4. INSTITUTIONAL CONTROLS UNDER CERCLA $\ldots \ldots \ldots \ldots \ldots \ldots \ldots$

4.1. Institutional Controls and the Baseline Risk Assessment $\ldots \ldots \ldots \ldots \ldots$

4.2. Institutional Controls and the Feasibility Study $\ldots \ldots \ldots \ldots \ldots \ldots$

5. INSTTTUTIONAL CONTROLS UNDER OTHER AUTHORITIES . . . . . . 5

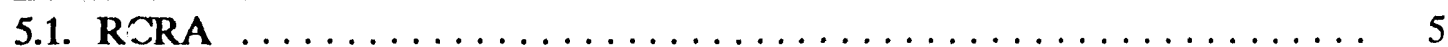

5.2. Radiation Regulatory Authorities $\ldots \ldots \ldots \ldots \ldots \ldots \ldots \ldots \ldots \ldots \ldots \ldots$

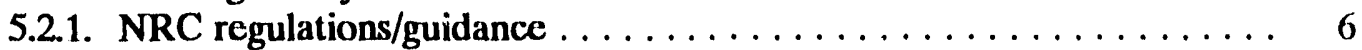

5.2.2. DOE orders $\ldots \ldots \ldots \ldots \ldots \ldots \ldots \ldots \ldots \ldots \ldots \ldots \ldots \ldots$

5.2.3. EPA standards for disposal of high level radioactive waste . . . . 8

6. CASE STUDY: SWSA $6 \ldots \ldots \ldots \ldots \ldots \ldots \ldots \ldots \ldots \ldots$

7. IMPACTS OF INSTITUTIONAL CONTROL AT DOE FACILITIES $\ldots \ldots \ldots \quad 12$

8. CURRENT DOE-OR/ER APPROACHES $\ldots \ldots \ldots \ldots \ldots \ldots \ldots \ldots \ldots$

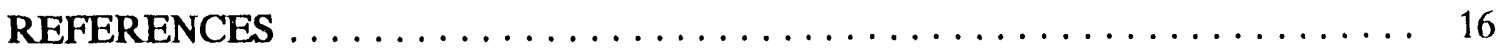

\section{DISCLAIMER}

This report was prepared as an account of work sponsored by an agency of the United States Government. Neither the United States Government nor any agency thereof, nor any of their employees, makes any warranty, express or implied, or assumes any legal liability or responsibility for the accuracy, completeness, or usefulness of any information, apparatus, product, or process disclosed, or represents that its use would not infringe privately owned rights. Reference herein to any specific commercial product, process, or service by trade name, trademark, manufacturer, or otherwise does not necessarily constitute or imply its endorsement, recommendation, or favoring by the United States Government or any agency thereof. The views and opinions of authors expressed herein do not necessarily state or reflect those of the United States Government or any agency thereof. 


\begin{abstract}
The United States Environmental Protection Agency (EPA), in the National Oil and Hazardous Waste Pollution Contingency Plan (NCP), has determined that institutional controls cannot be applied when determining human health risks from exposure to contaminants present at a hazardous waste site. This report summarizes some of the major issues related to the use of institutional controls at hazardous waste sites under the auspices of the Department of Energy Field Cffice, Oak Ridge/Environmental Restoration (DOEOR/ER) Division. In particular, the report addresses the impacts that assumptions regarding institutional controls have on the results and interpretation of the risk assessment, in both the Remedial Investigation (RI) and the Feasibility Study (FS).
\end{abstract}

Currently, access by the public is prohibited at the majority of hazardous waste sites under the auspices of the DOE-OR/ER Division. Fences, armed security guards, and patrols exclude the public from on-site areas. However, the length of time that the DOE-OR/ER sites will remain under active institutional controls is open to question. The answer might be tens, hundreds, or perhaps thousands of years. We can be reasonably sure that the controls will be in place tomorrow. In the long run, we can also be reasonably certain, in most cases, that the human health risks at the site will diminish through time due to the natural attenuation of contaminants and radioactive decay. But suppose we assume that institutional controls are renioved immediately and that a hypothetical family sets up residence on a DOEOR/ER hazardous waste site tomorrow. Our health risk estimates for that family would be far greater than actual current public risks with institutional controls, and would exceed the 
risks that would occur in the more likely event that institutional controls are not removed tomorrow, but in a hundred years.

The issue of institutional controls is having, and will continue to have, a direct impact at DOE-OR/ER sites, both in assessing baseline risks and in selecting feasible remedial action alternatives. Other DOE facilities should expect similar impacts. Institutional control assumptions determine the individual human receptor used to define the reasonable maximum exposure scenario. If the baseline risk assessment considers risks in the absence of institutional controls as the NCP requires, then the reasonable maximum exposure would be defined by a family setting up residence on the hazardous waste sites, conceivably growing crops and raising livestock there. The ultimate magnitude of the resulting hypothetical risk estimate is in many cases likely to be alarmingly high.

The DOE-OR/ER risk assessment program has studied the issues regarding the use of institutional controls and recommends the following approaches:

- Adhere to the NCP's requirement for assessing risks in the absence of institutional controls in the baseline risk assessment.

- Follow EPA's Region IV's definition of industrial and non-industrial sites immediately, and consider the appropriate exposure scenarios under the current and future land use conditions. 
- In addition to estimating risks in the absence of institutional controls, calculate current risks with institutional controls in place, and future risks when institutional controls are removed.

- For future exposure scenarios, define the period of time over which we expect the institutional controls to remain in place, based on similar approaches used by the radiation regulators.

The DOE-OR/ER risk management program recommends the following actions:

- The issue of institutional controls is of such importance that DOE should immediately correspond with EPA informing them of DOE-OR/ER's current approach and strategy, and requesting written guidance.

- DOE Headquarters should establish a national panel of experts to evaluate a reasonable and consistent approach to institutional controls at the DOE federal sites. 


\section{PURPOSE}

This report summarizes some of the major issues related to the use of institutional controls at hazardous waste sites under the auspices of the Department of Energy Field Office, Oak Ridge/Environmental Restoration (DOE-OR/ER) Division. In particular, the report addiesses the impacts that assumptions regarding institutional controls have on the results and interpretation of the risk assessment, both in the Remedial Investigation (RI) and the Feasibility Study (FS). Environmental restoration activities at DOE-OR/ER sites are primarily driven by CERCLA. Therefore, the report focuses on the approaches and assumptions relating to institutional controls under CERCLA. Also the report briefly outlines approaches adopted under other authorities such as RCRA and radiation regulatory authorities (such as NRC regulations/guidance, DOE orders, and EPA standards) in order to contrast these approaches to those adopted under CERCLA. In order to demonstrate the implications of the use of institutional controls at DOE facilities, this report summarizes the approaches and results of the recent baseline risk assessment for Solid Waste Storage Area 6 at Oak Ridge National Laboratory. The report concludes with possible options on the use of institutional controls at DOE-OR/ER sites.

\section{DEFINITION}

Institutional controls at hazardous waste sites are remedial response actions that mitigate health risks by limiting human activities or access to the site. Institutional controls do not involve reduction of the toxicity, volume, or mobility of the hazardous waste (although they may be used in conjunction with actions that do involve such reductions). Institutional controls act by physically restricting land-use of the site; for example, by erecting and

maintaining fences with security guards, patrols, and warning signs. They may also involve 
legal land/resource restrictions such as deed restrictions, deed notices, well-drilling prohibitions, well-use advisories, and building permits.

\section{IMPLICATIONS}

Currently, access by the public is prohibited at the majority of hazardous waste sites under the auspices of the DOE-OR/ER Division. Fences, armed security guards, and patrols exclude the public from on-site areas. However, the length of time that the DOE-OR/ER sites will remain under active institutional controls is open to question. The answer might be tens, hundreds, or perhaps thousands of years. We can be reasonably sure that the controls will be in place tomorrow. In the long run, we can also be reasonably ccrtain, in most cases, that the human health risks at the site will diminish through time due to the natural attenuation of contaminants and radioactive decay. But suppose we assume that institutional controls are removed immediately and that a hypothetical family sets up residence on a DOEOR/ER hazardous waste site tomorrow. Our health risk estimates for that family would be far greater than actual current public risks with institutional controls, and would exceed the risks that would occur in the more likely event that institutional controls are not removed tomorrow, but in a hundred years.

The residential risk exercise just described, although hypothetical, is not a futile one. If hypothetical risks to an on-site resident are unacceptable, then this argues strongly that DOE-OR/ER should keep in place the very active institutional control mechanisms that prevent those risks from actually occurring. The danger lies in the fact that estimates resulting from this risk assessment approach may mislead and overly distress the gencral public. There may be a perception amongst the general public that they are actually subjected to the risk level estimates generated by the exercise. 


\section{INSTITUTIONAL CONTROLS UNDER CERCLA}

\subsection{Institutional Controls and the Baseline Risk Assessment}

According to the National Contingency Plan (NCP), which implements the regulatory requirements established under CERCLA, the baseline risk assessment must consider risk $\underline{\text { in }}$ the absence of any institutional controls (NCP, section $300.430(\mathrm{~d}))^{1}$. The baseline risk assessment should address the potential land use associated with the highest level of exposure and risk. Because DOE-OR/ER sites currently have institutional controls in place, this means that the baseline risk assessment must consider an assumed future land use condition in which one cannot exclude the possibility that a family takes up residence on the sites. However, the NCP does concede that the assumption of future residential land use may not be justifiable if there is only a small probability that the site will support such use. Where the future land use is unclear, risks associated with residential land use should be compared to risks associated with other land uses, such as industrial, recreational, agricultural, etc.

EPA Region IV also have issued a baseline risk assessment guidance memorandum that addresses the exposure scenarios to be assessed under curient and future land use concitions $^{2}$. The directives are summarized as follows.

Instead of attempting to define an institutional control period, EPA Region IV has provided instructions to divide exposure scenarios into current and future land use (with no mention of the time frame, i.e., when the "future land use" will occur). Table 1 shows that the exposure scenarios to be considered also depend on whether the site is defined as industrial or non-industrial. EPA Region IV defines industrial sites as strictly buildings and their associated infrastructure. This definition of an industrial site means that a large 
Table 1. Land use assumptions for bascline risk assessments - from EPA Region IV Baseline Risk Assessment Guidance

Type of site

Current Land Use

Future Land Use

On-site non-industrial ${ }^{a, b}$

Off-site residential

On-site residential

On-site occupational ${ }^{\mathrm{c}}$

Inadvertent intruder

On-site industrial

Off-site residential

On-site occupational

Off-site residential

Inadvertent intruder

On-site occupational

Inadvertent intruder

a "on-site" means those areas that are fenced and patrolled

$b$ "industrial" sites are strictly buildings and their associated infrastructure

$c$ the on-site worker is a worker not involved with the investigation and remediation of the site 
number of the DOE-OR/ER hazardous waste sites will be considered non-industrial. Therefore, under the future land use condition, the baseline risk assessment must use the onsite residential "homesteader" scenario. Furthermore, this assessment under the future land use condition must consider exposures to current contaminant concentrations, even though these concentrations are likely to decrease through time due natural attenuation and radioactive decay.

\subsection{Institutional Controls and the Feasibility Study}

During the Feasibility Study, remedial action alternatives are developed, screened, and analyzed with respect to their ability to protect human health and the environment and other criteria, so that decision makers can select the appropriate alternative for the site. The NCP describes a number of expectations related to the role of institutional controls in selecting the remedial alternative ${ }^{1}$. The NCP states that institutional controls may be used as a supplement to engineered controls but may not substitute for Active Response Measures (ARMs) unless 1) ARMs are not practicable, as determined by remedy selection criteria, or 2) institutional controls are the only means available to provide protection of human health $[\mathrm{NCP}$, sections 300.430(a)1(iii)(d) and 300.430(e)3(ii)]. If institutional controls are used as a sole remedy, the special precautions must be taken to ensure institutional controls will remain reliable and in place.

Public comment on the NCP urged an expanded role for institutional controls if they could provide a similar level of protection at lower costs (particularly for federal sites). However, the EPA disagreed and refused enhancement or enlargement of the role of institutional controls ${ }^{1}$. 


\section{INSTTTUTIONAL CONTROLS UNDER OTHER AUTHORITIES}

\subsection{RCRA}

RCRA does not explicitly acknowledge the use of institutional controls in the RCRA Facility Investigation, although the permitting requirements generally include a 30-year postclosure active control period. The RCRA process involves setting media cleanup target levels at a point of compliance that is negotiated early in the process. RCRA does allow remedial action alternaives that include measures that are not directly related to media clean-up, source control or waste management (e.g., neasures to control exposures) as long as the alternative is protective of human health and the environment, reduces or eliminates further releases, and complies with management standards ${ }^{3}$.

\subsection{Radiation Regulatory Authorities}

R.adiation-specific regulations are more explicit and tolerant about the use of institutional controls than are CERCLA or RCRA. Radiation requirements for the disposal and management of waste generally involve setting acceptable doses to the public and equivalent concentrations that are calculated assuming a given period of institutional control ${ }^{4}$. We describe specific regulations and associated institutional control periods below, and summarize them in Table 2.

\subsubsection{NRC regulations/guidance}

The NRC Part 61 requirements for the near-surface disposal of radioactive waste identify three classes of radioactive waste ${ }^{5}$. The concentration limits depend on specific disposal requirements and assumed scenarios for inadvertent intrusion for the different 
Table 2. Assumed periods of institutional control under different radiation regulatory authorities.

\begin{tabular}{|c|c|c|}
\hline Standard & Type of Facility & $\begin{array}{l}\text { Assumed Period of Institutional } \\
\text { Control }\end{array}$ \\
\hline \multirow[t]{2}{*}{ NRC Part $61^{5}$} & $\begin{array}{l}\text { Near-surface disposal of } \\
\text { radioactive waste }\end{array}$ & $\begin{array}{l}\text { Class } C \text { waste: } \\
100 \text { years active control } \\
400 \text { years passive control }\end{array}$ \\
\hline & & $\begin{array}{l}\text { Class } A \text { and } B \text { waste: } \\
100 \text { years active control }\end{array}$ \\
\hline DOE Order $5820.2 \mathrm{~A}^{6}$ & $\begin{array}{l}\text { Near-surface disposal of } \\
\text { low level waste }\end{array}$ & 100 years active control \\
\hline \multirow[t]{2}{*}{ EPA CFR Part $191^{7,8}$} & \multirow{2}{*}{$\begin{array}{l}\text { Groundwater protection } \\
\text { standards for disposal of } \\
\text { high level waste }\end{array}$} & $\begin{array}{l}1,000 \text { years (no direct } \\
\text { intrusion })^{7}\end{array}$ \\
\hline & & $\begin{array}{l}1,000 \text { or } 10,000 \text { years (no } \\
\text { direct intrusion) }\end{array}$ \\
\hline
\end{tabular}


classes. Waste with the highest activities are designated as Class $\mathrm{C}$ waste. For these wastes, an active institutional control period of 100 years is assumed. After 100 years, it is assumed that active institutional centrols are removed and the public may intrude on the site, but that the specific requirements for disposal of Class $C$ waste (capping, burial at depths below $5 \mathrm{~m}$ ) prevent direct exposure for an additional 400 years.

An active institutional control period of 100 years is also assumed for Class A and B wastes. However, because of their lower activities, there are no specific disposal requirements that would prevent direct exposure after institutional controls are terminated.

\subsubsection{DOE orders}

DOE Order 5820.2A for the management of low level waste specifies limits on annual doses for inadvertent intruders after loss of active institutional controls at 100 years after disposa!".

\subsubsection{EPA standards for disposal of high level radioactive waste}

The EPA 40 CFR Part 191 groundwater protection requirements for management and disposal of spent nuclear fuel, high-level and transuranic waste set annual dose limits and concentration limits for 1000 years after disposal, assuming undisturbed performance (e.g., no direct human intrusion) ${ }^{7}$. However, the First Circuit Court vacated these requirements, finding them arbitrary in limiting the duration of the requirement to 1000 years. The EPA apparently plans to propose alternative time periods of 1000 and 10,000 years for the application of the requirements ${ }^{8}$. 


\section{CASE STUDY: SWSA 6}

Solid Waste Storage Area 6 (SWSA 6) is part of Waste Arca Grouping VI at the Oak Ridge National Laboratory (ORNL). SWSA 6 is approximately $2.9 \mathrm{~km}$ southwest of the ORNL Main Plant, covers an area of 15 acres, and occupies most of the total acreage of WAG VI (Fig. 1). Since 1969, low level radioactive and chemically hazardous wastes from operational and research activities conducted at ORNL have been deposited at SWSA 6. These include contaminated soil, laboratory equipment, protective clothing, mechanical equipment, construction materials, filter media and resins, radioactive waste, and animal remains. Packaging of wastes ranged from no packaging to stainless steel drums. Since May 1986, radioactive wastes have been stored in underground concrete silos.

SWSA 6 is fenced and regularly patrolled by armed security guards. There is no public access. The entrance is continually guarded and access is limited to ORNL employees with clearance for entering the specific area.

Table 3 shows the exposure scenarios that were used in the baseline risk assessment. The assessment included an off-site residential exposure scenario -- the "off-WAG Clinch River Homesteader" in Table 3. The hypothetical homesteader was placed beside the Clinch River, 9.5 miles downstream of the site, adjacent to the boundaries of the Oak Ridge Reservation. This scenario was used to provide a measure of the potential public risks posed by the site with the rurrent instituional controls in place. Current risk estimates for this scenario were on the order of $10^{-5}$, primarily due to external exposure to cesium-137 in the soil ${ }^{9}$. The current institutional controls apparently are effective in reducing public risks from the site to levels that are within the EPA's acceptable risk range. 


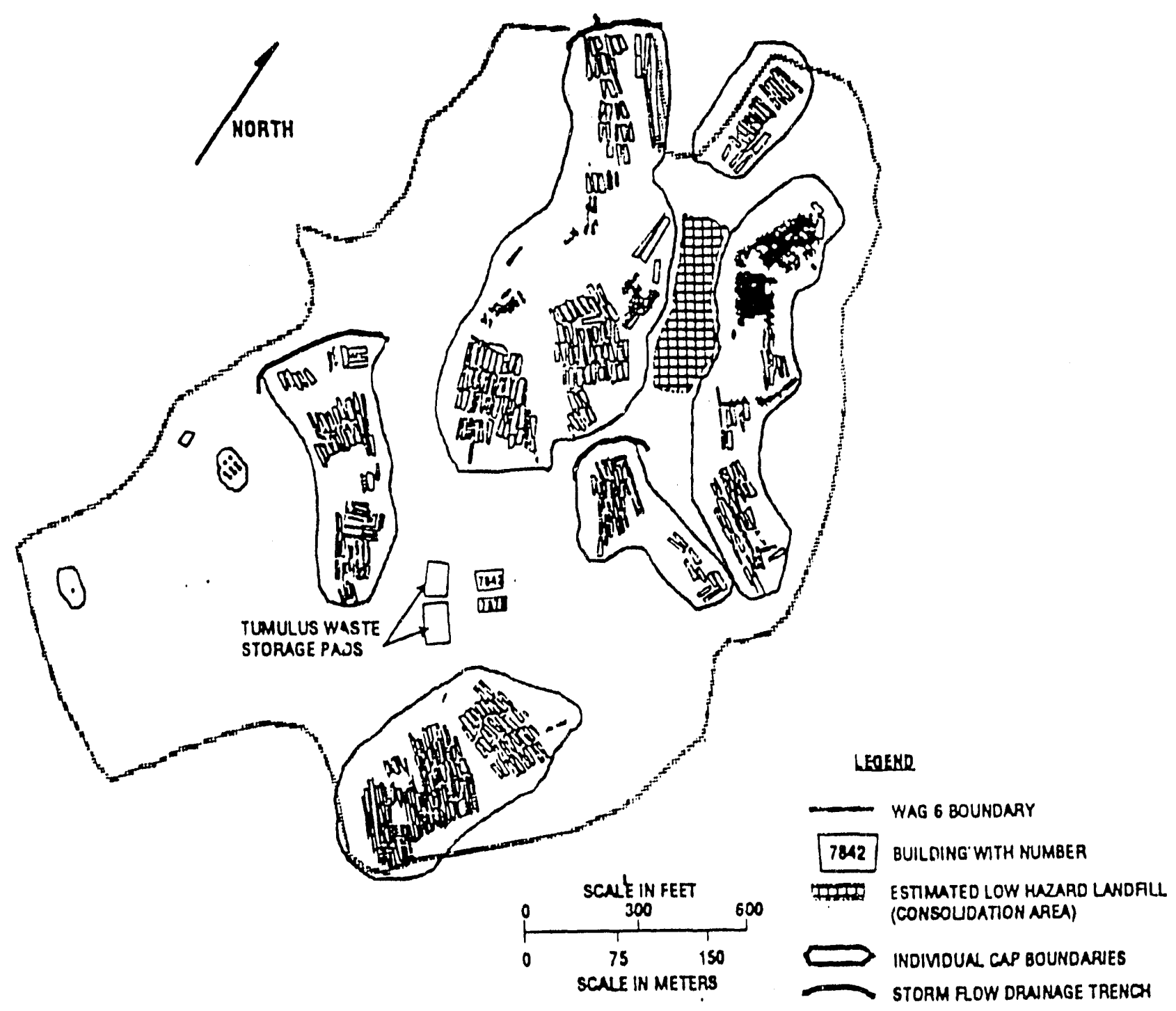


Table 3. Significant SWSA 6 receptor scenarios.

\begin{tabular}{|c|c|c|c|}
\hline \multirow{2}{*}{$\begin{array}{l}\text { POTENTIAL } \\
\text { AECEPTORS }\end{array}$} & \multicolumn{3}{|c|}{ PEALOD OF INSTITUTIONAL CONTAOL } \\
\hline & \multicolumn{2}{|c|}{$\begin{array}{c}\text { COMTROLLED } \\
\text { (OPERATIONAL: } 0.10 \text { YA \& POST.OPEAATIONAL: }=10.110 \mathrm{YR}\end{array}$} & \multirow{2}{*}{$\begin{array}{c}\text { UNCONTROLLED (1) } \\
\text { (NOHOPERATIOHALS } 110 \text { YA) } \\
\text { WAO G AREA }\end{array}$} \\
\hline & ON-WAO & OFF.WAO & \\
\hline $\begin{array}{l}\text { WAO } \\
\text { BOUNDARY. } \\
\text { HUNTER } \\
\text { AECEPTOR }\end{array}$ & & - MOESTION-FAUMA (A,C) & \\
\hline $\begin{array}{l}\text { WAO G M } \\
\text { BOUNDAAY. } \\
\text { FENCEPOST } \\
\text { RECEPTOR }\end{array}$ & & $\begin{array}{l}\text { - DGALATIOH-ALA (R,C) } \\
\text { - DARECT RAOLATIOHSOL (A) }\end{array}$ & \\
\hline $\begin{array}{l}\text { WAQ } 6 \text { ORNL } \\
\text { EMPLOYEE }\end{array}$ & $\begin{array}{l}\text { - INHALATIOH-AAP (AKA,C) } \\
\text { - DIAECT RADAATION.SOLL (A) }\end{array}$ & & \\
\hline $\begin{array}{l}\text { OW-WAG (S) } \\
\text { HOMESTEADER }\end{array}$ & 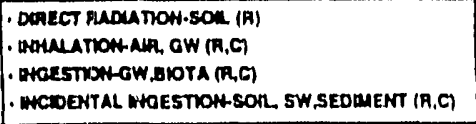 & & 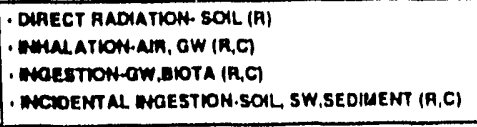 \\
\hline $\begin{array}{l}\text { OFF.WAG (SK(B) } \\
\text { CLNCH AIVER } \\
\text { HOMESTEADER }\end{array}$ & · & 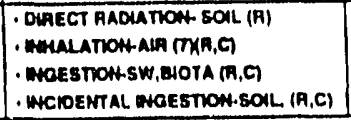 & \\
\hline
\end{tabular}

KEY: OW " OROLUNDWATEA

SW - SURFACE WATEA

A A ASSESSED FOA RAONONUCLOE COMPONEM

C I ASSESSED FOA CHEMICAL COMPONENTS

1. WAO S AAEA W UHCONTROLLD PERIOD, WO WAQ OOUNDAATES EXIST.

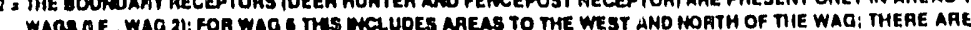

WAQS RE WAG 2): FOR WAO O THS WHCLUDES NAEAS TO THE WEST AND HOFTH OF TIE WAG: THEGE

WO EURFACE WATER DRAWAOES EXTTNO THE WAQ FHOM THESE AHEAS, TH

WATENSEDDENT EXPOSUAES ARE ANTCAPATED FOA THIS HECEPTOA.

4. WGU UOES DAHALATOH OF VOUATLES AND PANTCULATES FOA ML AH EXPOSUAE ROUTES.

S. W ADOTON TO THE TME FHAMES WNOKCATED, MAXMUA CONCEMTAATONS ASSOCAATED WTH THE LDENTIFTED

ETOSURE MOUTES AHO MEE YEAR THEY OCCUA MLL ALSO DE PAOVDED.

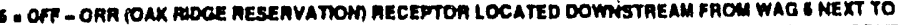

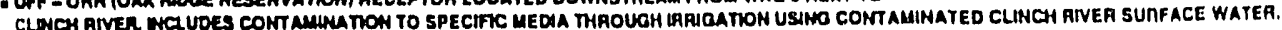

7 . ASSESSED FOA TRMTUL OAR. $r$. 
As required under CERCLA, the baseline risk assessment also included an evaluation of risk in the absence of institutional controls. Thus, the risk assessment included an on-site residential exposure scenario -- the "on-WAG homesteader" scenario in Table 3. Using estimates of current contaminant levels, the main source of risk for this hypothetical exposure scenario was from external exposure to europium-154 while excavating the soil to build the house. Estimates of current risk from this pathway alone approached unity (i.e., almost a $100 \%$ probability of developing cancer). Estimates of risk 110 years later for the same pathway and for europium-154 alone were similar to current risk estinates, but risks 500 years later had essentially disappeared due to the radioactive decay of europium-154. (Risks from other pathways and contaminants were on the order of $10^{-3}$ after 500 years.) Clearly, this case study suggests that the DOE should keep active institutional control measures in place for at least 500 years.

\section{IMPACTS OF INSTITUTIONAL CONTROL AT DOE FACILITIES}

The issue of institutional controls is having, and will continue to have, a direct impact at DOE-OR/ER sites, both in assessing baseline risks and in selecting feasible remedial action alternatives. Other DOE facilities should expect similar impacts. Institutional control assumptions determine the individual human receptor used to define the reasonable maximum exposure scenario. If the baseline risk assessment considers risks in the absence of institutional controls as the NCP requires, then the reasonable maximum exposure would be defined by a family setting up residence on the hazardous waste sites, conceivably growing crops and raising livestock there. The ultimate magnitude of the resulting hypothetical risk estimate is in many cases likely to be alarmingly high, as the SWSA 6 case study shows. 
However, the concept of assessing baseline risks in the absence of institutional controls is a valid one. The assessment predicts what possible risk levels could be if the current institutional controls were to be removed. However, it is important that the general public are not given the impression that they are actually subjected to the estimated risk levels. Therefore, DOE-OR/ER risk assessments should also include an assessment of risks with the present institutional controls (fences, guards, patrols, etc.) in place, as well as future risks when the institutional controls are removed after some period of time. For the assessment of future risks, one needs to define the period of time over which we expect the institutional controls to remain in place, as the radiation regulators have done. In general, the longer the time period, the lower the eventual risks when cortrols are removed because of natural attenuation of contaminants and radioactive decay.

The role of institutional controls in selecting feasible alternatives will also have an impact at DOE-OR/ER and other DOE sites. The NCP emphasizes the use of engineered alternatives for remediation. Institutional controls are intended to supplement, but not replace, such active response measures. However, perhaps the current institutional control measures at DOE-OR/ER sites are more effective in terms of overall protection of human health and the environment than are present-day engineering technologies. The SWSA 6 case study suggests that an appropriate period of institutional controls would be on the order of 500 years due to the presence of long-lived radionuclides.

\section{CURRENT DOE-OR/ER APPROACHES}

The DOE-OR/ER risk assessment program has discussed these issues and recommends the following approaches. 
1. Adhere to the NCP's requirement for assessing risks in the absence of institutional controls in the baseline risk assessment. Follow EPA's Region IV's definition of industrial and non-industrial sites (Table 1) immediately, and consider the appropriate exposure scenarios under the current and future land use conditions as summarized above. Under the future land use condition for non-industrial sites, the on-site resident homesteader will hypothetically be exposed to the current contaminant concentrations in most cases. However, if fate and transport models predict that contaminant concentrations may increase through time, then the predicted concentrations would be used rather than the current concentrations. All exposure scenario assumptions will be qualified in the "uncertainties" section of the baseline risk assessment.

2. In addition to estimating risks in the absence of institutional controls, calculate current risks with institutional controls in place, and future risks when institutional controls are removed. Under the future land use condition, use fate and transport models to provide realistic estimates of future exposures. Present collectively in the baseline risk assessment all risk estimates for the different exposure scenarios along with assessments of the likelihood of the scenarios occurring.

3. For future exposure scenarios define the period of time over which we expect the institutional controls to remain in place based on similar approaches used by the radiation regulators. Time periods could be developed on a generic basis or they could be determined on a site-specific basis, but they must be fully justified. 
4. The issue of institutional controls is of such importance that DOE should immediately correspond with EPA informing them of DOE-OR/ER's current approach and strategy, and requesting written guidance.

5. DOE Headquarters should establish a national panel of experts to evaluate a reasonable and consistent approach to institutional controls at the DOE federal sites. The panel will evaluate the reasonableness of EPA's approaches for the baseline risk assessment. The panel will also discuss the use of institutional controls as a component of the remedial alternatives developed at DOE-OR/ER sites. In addition, the panel will consider the validity of problems involved with DOE's stewardship authority of lands and facilities for periods longer than 100 years. Because the presence of long-lived radionuclides at many of the DOE-OR/ER sites means that 100 ycars will not be sufficient, as the SWSA 6 case study shows, DOE has two alternatives:
A) Examine the DOE's authority to commit to perpetual stewardship/guardianship of the sites.
B) Propose alternative time periods for DOE's commitment to keeping
institutional controls in place. Time periods could be developed on a generic basis or they could be determined on a site-specific basis. 


\section{REFERENCES}

1. U.S. Environmental Protection Agency. "National Oil and Hazardous Substance Pollution Contingency Plan." The Federal Register 55, No. 46, 1990.

2. Environmental Protection Agency, Region IV. "Bascline Risk Assessment Guidance," 1990.

3. Environmental Protection Agency. "Corrective Action for Solid Waste Management Units at Hazardous Waste Management Facilities," Proposed Rule. The Federal Agency 55, No. 27, 1990.

4. Kocher, D.C. "Applicable or Relevant and Appropriate Regulatory Requirements for Remediation of Radioactively Contaminated Waste Disposal Sites." Oak Ridge National Laboratory (ORNL/ER-31), 1991.

5. U.S. Nuclear Regulatory Commission. "Part 61-Licensing Requirements for Land Disposal of Radioactive Waste," p. 93 in Code of Federal Regulations, Title 10, Parts 51 to 199, U.S Government Printing Office, Washington, D.C., 1989.

6. U.S. Department of Energy. "Management of Low Level Waste," Chapter III in “Radioactive Waste Management," Order 5820.2A, 1988. 
7. U.S. Environmental Protection Agency. "Part 191 - Environmental Radiation Protection Standards for Management and Disposal of Spent Nuclear Fuel, HighLevel and Transuranic Waste," p. 7 in Code of Federal Regulations, Title 40, Parts 190 to 399, U.S. Government Printing Office, Washington, D.C., 1988.

8. U.S. Environmental Protection Agency. "Part 191 - Environmental Radiation Prolection Standards for Management and Disposal of Spent Nuclear Fucl, HighLevel and Transuranic Waste," Working Draft 1, June 2, 1989

9. Martin Marietta Energy Systems, Inc. “RCRA Facility Investigation Report for Waste Area Grouping 6 at Oak Ridge National Laboratory, Oak Ridge, Tennessec.“ Vol. 2. 1991. 


\section{DISTRIBUTION}

1. L. D. Bates

2. W. R. Brown

3. K. W. Cook

4. T. K. Cothron

5. N. W. Durfee

6. C. D. Goins

7. B. L. Kimmel

8. J. R. Merriman

9. M. E. Mitchell

10. J. H. O'Brien

11-12. P. T. Owen

13. F. S. Patton

14. G. E. Rymer

15. D. W. Swindle

16. C. C. Travis

17. W. W. Thompson, Jr.

18-27. R. K. White

28. Central Research Library

29-33. ER Document Management Center

34. ORNL Laboratory Records

35. P. H. Edmonds, Radian Corporation, 120 South Jefferson Circle, Oak Ridge, TN 37830

36-39. W. E. Murphie, Department of Energy, Office of Environmental Restoration, Eastern Area D\&D Branch, EM-423 (GTN), Washington, DC 20545

40-41. S. S. Perkins, Department of Energy Field Office, Oak Ridge, Information Resource Center, 105 Broadway, Oak Ridge, TN 37830

42-51. R. C. Sleeman, Department of Energy Field Office, Oak Ridge, P.O. Box 2001, Oak Ridge, TN 37831-8541

52. S. K. Lankford, Department of Energy Oak Ridge Field Office, P.O. Box 2001, Oak Ridge, TN 3783!-8541

53. M. A. Travaglini, Department of Energy Oak Ridge Field Office, P.O. Box 2001, Oak Ridge, TN 37831-8541

54. S. P. Riddle, Department of Energy Oak Ridge Field Office, P.O. Box 2001, Oak Ridge, TN 37831-8541

55. D. G. Page, Department of Energy Oak Ridge Field Office, P.O. Box 2001, Oak Ridge, TN 37831-8541

56. C. S. Gist, Department of Energy Oak Ridge Field Office, P.O. Box 2001, Oak Ridge, TN 37831-8541

57. W. D. Adams, Department of Energy Oak Ridge Field Office, P.O. Box 2001, Oak Ridge, TN 37831-8541

58-59. Office of Scientific and Techrical Information, P.O. Box 62, Oak Ridge, TN 37831 

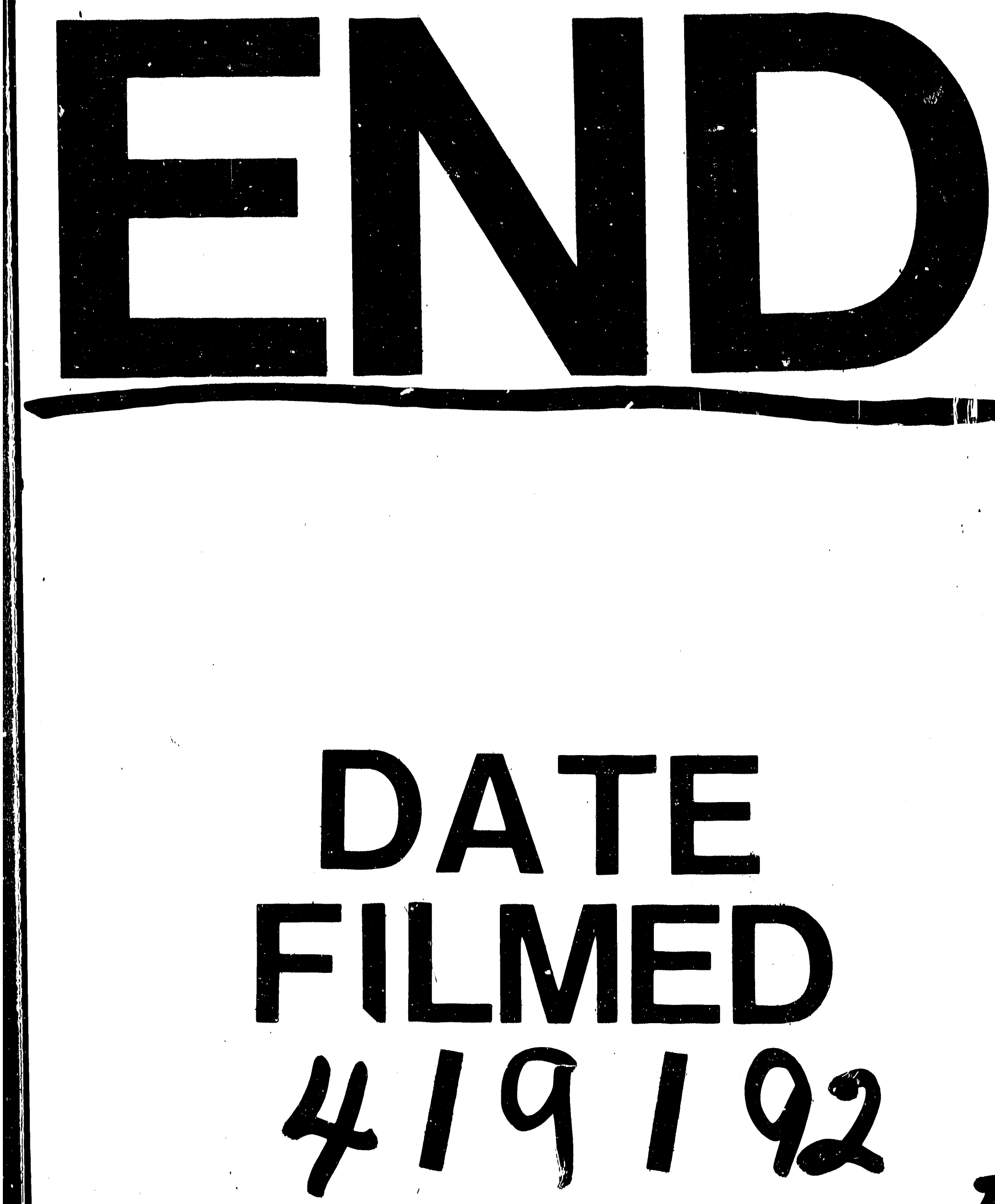

$I$ 